University of Nebraska - Lincoln

DigitalCommons@University of Nebraska - Lincoln

Faculty Publications from the Harold W. Manter Laboratory of Parasitology

8-1970

\title{
A Syncoeliid (Hemiuroidea Faust, 1929) Metacercaria on a Copepod from the Atlantic Equatorial Current
}

Robin M. Overstreet

Gulf Coast Research Laboratory, robin.overstreet@usm.edu

Follow this and additional works at: https://digitalcommons.unl.edu/parasitologyfacpubs

Part of the Parasitology Commons

Overstreet, Robin M., "A Syncoeliid (Hemiuroidea Faust, 1929) Metacercaria on a Copepod from the Atlantic Equatorial Current" (1970). Faculty Publications from the Harold W. Manter Laboratory of Parasitology. 298.

https://digitalcommons.unl.edu/parasitologyfacpubs/298

This Article is brought to you for free and open access by the Parasitology, Harold W. Manter Laboratory of at DigitalCommons@University of Nebraska - Lincoln. It has been accepted for inclusion in Faculty Publications from the Harold W. Manter Laboratory of Parasitology by an authorized administrator of DigitalCommons@University of Nebraska - Lincoln. 


\section{A Syncoeliid (Hemiuroidea Faust, 1929) Metacercaria on a Copepod from the Atlantic Equatorial Current}

The complete life cycle for a species of Syncoeliidae Odhner, 1927, is unknown. Adults are known from the branchial cavity and mouth of marine fishes which are usually found off- shore, and second intermediate hosts have been reported. Sars (1885, Challenger Rept. Zool. 13: 228 p.) described the metacercaria of Syncoelium filiferum from the perivisceral cavity 
of the euphausiids Nematoscelis megalops Sars, 1883, and Thysanoessa gregaria Sars, 1883, in the South Atlantic. Dollfus (1966, Bull. Mus. Natl. Hist. Nat. Ser. 2 38: 195200) described Metacercaria (Gen. ?) theomonodi from some poorly preserved material amidst a collection of "copepods and chaetognaths" collected off Cape Verde Islands. I concur with Dr. H. W. Manter and Mrs. M. H. Pritchard who, in a footnote in Dollfus' paper, identified the worm as a species of Paronatrema Dollfus, 1937. A photograph was presented of the worm attached externally to the euphausiid Nyctiphanes couchii (Bell, 1853). The following report is the first of an external attachment for a larval member of the genus Syncoelium Looss, 1899, and the first of a documented association with a copepod.

On 23 February 1966 (2200 to $2400 \mathrm{hr}$ ) at $02^{\circ} 00^{\prime} \mathrm{N}, 46^{\circ} 58^{\prime} \mathrm{W}$ (near the mouth of the Amazon River), Dr. Harding B. Owre, of the University of Miami, aboard the $\mathrm{R} / \mathrm{V}$ Jorn ElliotT PILlsbury (cruise supported by N8245 with biological support from N8254), collected from the surface water a specimen of the copepod Candacia pachydactyla (Dana, 1852) with a trematode firmly attached to the right thoracic spine. She took notes on a lengthy observation of the worm, during which it remained attached to the same site. The worm and host were relaxed in ethyl alcohol before fixing and later kindly donated to me. They were then stained in Van Cleave's hematoxylin.

\section{Syncoelium sp.}

(Figs. 1, 2)

\section{Description (measurements in microns)}

Body 2,257 long; forebody 53\% of body length, with small papillae on thick cuticle. Acetabulum subterminal on $389-\mu$-long peduncle. Oral sucker slightly wider than acetabulum. Minute spines in both suckers. Preoral lip well developed. Pharynx 163 long by 109 wide. Esophagus 116 long. Ceca sinuous, joining at 56 from posterior end of body.

Testes, in tandem rows of 5 on right and 6 on left, 74 to 112 long by 128 to 159 wide. Seminal vesicle sinuous, extending from anterior testes to a short distance posterior to pharynx. Pars prostatica muscular, sinuous, surrounded by numerous small prostatic cells. Hermaphroditic duct 135 long, accepting male duct at level of posterior border of pharynx. Genital atrium about 106 long. Duct and atrium surrounded by conspicuous mass of muscle.

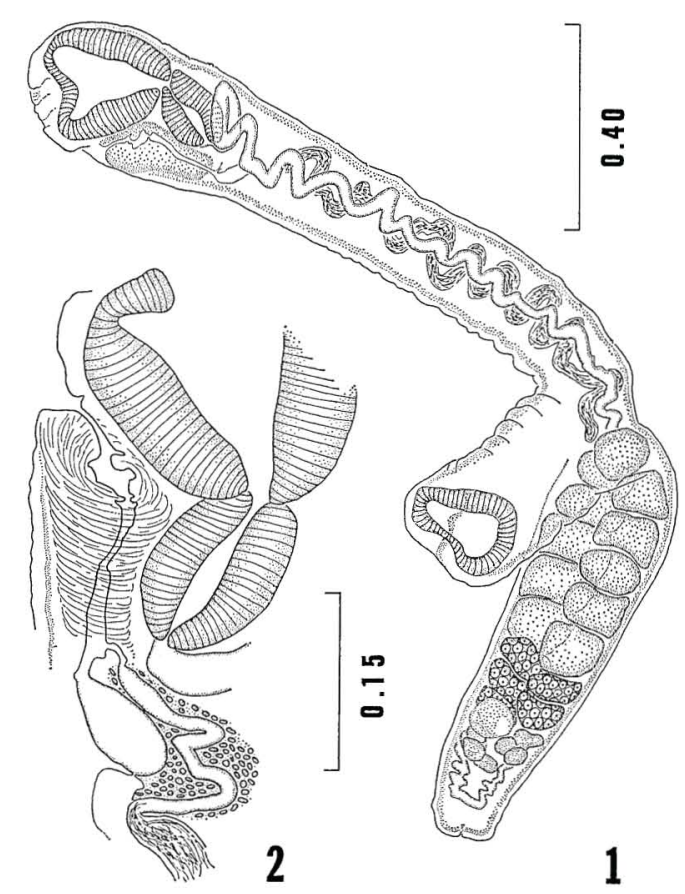

Figures 1, 2. Metacercaria of Syncoelium sp. 1. Ventrolateral view showing anterior portion of left cecum. 2. Terminal reproductive organs. Scale values are millimeters.

Ovaries posttesticular, in tandem rows of 3 on right and 2 on left, 58 to 72 long by 105 to 112 wide. Vitellaria 7 lobes, 4 on right and 3 on left. Mehlis' gland larger than and ventral to posterior ovary. Uterus looped throughout hindbody. Metraterm 105 long.

Excretory pore terminal; vesicle-proper 19 long, forming 2 branches; branches coursing sinuously through hindbody and peduncle, fusing dorsal to posterior portion of oral sucker.

\section{Remarks}

The status of the six described species of Syncoetium is uncertain. Some of the species have been described from few or immature specimens, and much emphasis has been placed on the number of testes, which apparently is not consistent in all species.

The present specimen has 11 testes, the same as S. ragazzii (Setti, 1897) as described by Looss (1899, Zool. Jahrb. Abt. Syst. 12: 521784 ), but differs from that species in having a stalked rather than a merely elevated acetabulum. Disregarding the number of testes, the metacercaria differs from S. spathulatum Coil and Kuntz, 1963, by possessing what appears to be a copulatory organ and from S. priacanthi 
Byrd, 1962, and S. katuwo Yamaguti, 1938, by having prostatic cells; it appears most similar to S. priacanthi or S. thyristae (Crowcroft, 1948), a species Manter (1954, Tr. Roy. Soc. New Zealand 82: 475-568) thought was probably S. filiferum of Sars (1885, loc. cit.) (not of Lloyd and Guberlet, 1936, Tr. Am. Micr. Soc.
55: $44-48)$. The metacercaria does not have the byssal filaments described by Sars (1885, loc. cit.) and Leuckart (1889, Bd., 1, Leipzig) for S. filiferum. There is not sufficient evidence for a new species.

Robin M. Overstreet, Gulf Coast Research Laboratory, Ocean Springs, Mississippi 39564 